\title{
A Comprehensive Approach to Patient-individual Glioblastoma Multiforme Model Establishment
}

\author{
Christina Susanne Mullins ${ }^{1,2}$, Björn Schneider ${ }^{3}$, Anne Lehmann², Florian Stockhammer ${ }^{4}$, Sascha Mann ${ }^{4}$, Carl-Friedrich Classen ${ }^{1}$ and \\ Michael Linnebacher ${ }^{2 \star}$
}

${ }^{1}$ University Children's Hospital, University Medicine Rostock, Germany

${ }^{2}$ Department of General Surgery, University Medicine Rostock, Germany

3 Institute for Pathology, University Medicine Rostock, Germany

${ }^{4}$ Department of Neurosurgery, University Medicine Rostock, Germany

\begin{abstract}
Patient-individual tumor models for Glioblastoma Multiforme (GBM) are important not only for basic and translational research but also for the development and improvement of optimal and individualized treatment strategies. The model that has gained widest acceptance is the primary cell culture model. The laborious and time consuming process is rewarded with a relative high initial success rate (about $60 \%$ ). We here describe and evaluate an extended biobanking methodology to simplify sample collection and model establishment. GBM resection specimen were collected ad hoc, partially prepared fresh for modeling, snap frozen for molecular testing and frozen down vitally.
\end{abstract}

The established models were subject to subsequent detailed characterization in direct comparison to the patients' tumors. Generally, molecular characteristics such as mutations, gene amplifications and epigenetic alterations were maintained in the models. Immortality, neuronal origin and stem cell characteristics of the cell lines could be demonstrated. Extensive drug sensitivity screens were performed. These well-defined patient-individual models are ideal for establishment of individualized therapy approaches and enable testing of immunological strategies.

Our extended biobanking procedure facilitates collection, long-time storage and propagation (modeling) of clinical GBM specimens (potentially also from distant centers) for basic research, (pre-) clinical studying of novel therapies and individual response prediction.

Keywords: Glioblastoma multiforme; In vitro models; Molecular characterization; Drug testing; Phenotyping

\begin{abstract}
Abbreviations: BTSC: Brain Tumor Stem Cell; CGH: Comparative Genomic Hybridization; EGFR: Epidermal Growth Factor Receptor; GBM: Glioblastoma Multiforme; IL-13Ra: Interleukin 13 receptor alpha; MGMT: $\mathrm{O}^{6}$-methylguanine-DNA methyltransferase; TAA: Tumor Associated Antigen; TMZ: Temozolomide; WHO: World Health Organization
\end{abstract}

\section{Introduction}

Glioblastoma Multiforme (GBM) is the most frequent neoplasm of the brain, characterized by a very dismal prognosis [1,2]. Despite multimodal treatment consisting of resection followed by irradiation and chemotherapy with temozolomide (TMZ), median survival only ranges from 9 to 12 months [3]. A highly invasive phenotype usually leads to local recurrence even after macroscopically complete resection [4]. Different approaches have been undertaken to classify and thus better stratify (e.g. with regard to optimal treatment strategies) these tumors. The World Health Organization (WHO) classification differentiates tumors according to their histology, morphology and degree of malignancy (WHO grade I-IV); GBM are astrocytic tumors WHO grade IV [5]. Those are divided into primary GBM appearing de novo as grade IV tumors and secondary GBM that progress from low grade to grade IV tumors [6]. Primary GBM are characterized by amplification and/or mutation of the epidermal growth factor receptor (EGFR), whereas secondary tumors typically show mutations in the genes IDH 1 and 2 [6]. The most recent approach classifies GBM by the origin of the tumor initiating cell type: pro-neural (oligodendrocytic cells), neural (neurons), mesenchymal (astroglia, microglia) and classical (astrocytic cells) GBM [7]. Especially the latter classification takes a variety of molecular characteristics into account, which is enabled by increasingly extensive molecular pathological profiling. Key analyses include methylation status of the $\mathrm{O}^{6}$-methylguanine-DNA methyltransferase (MGMT) promoter and mutational profiling of IDH 1 and 2, TP53, PTEN, RB-1, NF-1 and EGFR [8,9]. The mutation of EGFR coincides with an amplification of the receptor [10,11]. Finally, chromosomal changes such as loss of or loss of heterozygosity at $10 \mathrm{q}$ as well as loss of $1 \mathrm{p}$ and $19 \mathrm{q}$ (alone or as co-deletion) are common GBM features $[8,12]$.

Recently, Duarte and coworkers affirmed this concept by describing a gene signature (IFN/STAT1) in the proneural subtype which may be responsible for poor prognosis due to chemotherapy and/or radiation resistance in these tumors. Their results might have strong implications both for better prediction of survival outcome and for improved understanding of GBM subtype-specific tumor progression mechanisms and treatment response [13].

*Corresponding author: Michael Linnebacher, $\mathrm{PhD}, \mathrm{PI}$, Group leader, University Rostock, General Surgery, Schillingallee 69, Rostock, MV 18057, Germany, Tel: +49-381494-6043; Fax: +49-381-494-6002; E-mail: michael.linnebacher@med.uni-rostock.de

Received November 07, 2013; Accepted January 03, 2014; Published May 25 2014

Citation: Mullins CS, Schneider B, Lehmann A, Stockhammer F, Mann S, et al (2014) A Comprehensive Approach to Patient-individual Glioblastoma Multiforme Model Establishment. J Cancer Sci Ther 6: 177-187. doi:10.4172/19485956.1000269

Copyright: ( 2014 Mullins CS, et al. This is an open-access article distributed under the terms of the Creative Commons Attribution License, which permits unrestricted use, distribution, and reproduction in any medium, provided the original author and source are credited. 
Consequently, the heterogeneity of GBM must be considered in drug development and preclinical testing. Patient individual tumor models provide ideal material for such studies. These individual models are likely to allow the most accurate response and resistance prediction outside the patient. The high prediction precision of individual carcinoma models was demonstrated by Voskoglou-Nomikos and colleagues as well as by Fiebig and co-workers with $90 \%$ and even $97 \%$ accuracy for prediction of response and resistance, respectively $[14,15]$.

We here aimed at the establishment of a comprehensive collection of GBM cell models out of a consecutive series of clinical cases. In vitro cell line establishment was performed in parallel with in vivo engraftment into immunodeficient mice. And this model collection was subsequently deeply characterized taking the above described molecular classifications and markers well into account.

\section{Materials and Methods}

\section{Tumor specimen collection and cryopreservation}

Between August 2009 and October 2012, 42 clinical samples from patients with GBM WHO grade IV (Table 1) were collected from the Neurosurgery department at the University Medicine Rostock. Prior informed consent was obtained in written form from all patients, and all procedures were approved by the institutions' Ethics Committee (reference number: A 2009/34) in accordance with general accepted guidelines for the use of human material. Resection specimens of GBM tumors $(n=42)$ were received sterile and freshly from surgery. Tumor tissue samples were snap frozen in liquid nitrogen and stored in the gas phase above liquid nitrogen. Additionally, tumor tissue cubes $(3 \times$ $3 \times 3 \mathrm{~mm}$ ) were frozen vitally. For this procedure, tumor pieces were cut with a sterile scalpel blade, and 4 tumor pieces were transferred into one sterile cryo-tube in $1.5 \mathrm{ml}$ freezing medium (fetal calf serum containing $10 \% \mathrm{DMSO}$ ), sealed in a freezing container (Nalgene, Rochester, USA), and placed immediately at $-80^{\circ} \mathrm{C}$. Until unthawing, tubes were kept at $-80^{\circ} \mathrm{C}$ (for a maximum of 6 weeks) or, after overnight cooling, transferred into a nitrogen tank (for longer storage periods). For subsequent modeling procedures, cryopreserved tumor pieces were thawed at $37^{\circ} \mathrm{C}$.

\section{Xenografting into immunodeficient mice}

Tumor xenografting was done by one of the following approaches: (I) xenografting of fresh tumor pieces on the day of surgery $(n=10)$; (II) xenografting of tumor pieces after cryopreservation $(n=36)$; and (III) re-transplantation of xenografts $(n=3)$. Tumor pieces were implanted subcutaneously bilaterally into the flanks of six to eight week old female mice under short term ether anesthesia. We used NMRI nu/nu mice for the xenograftings. Mice were kept in the animal facilities of the University Medicine Rostock and maintained in specified pathogenfree conditions. Animals were exposed to $12 \mathrm{~h}$ light $/ 12 \mathrm{~h}$ darkness cycles and standard food and water including antibiotics (Co-trimoxazol) ad libitum. Their care and housing were in accordance with guidelines as put forth by the German Ethical Committee and the Guide for the Care and Use of Laboratory Animals (Institute of Laboratory Animal Resources, National Research Council; NIH Guide, vol.25, no.28, 1996). Growth of tumors to volumes of $1-1.5 \mathrm{~cm}^{3}$ was taken as evidence of successful xenografting, and the animals were then sacrificed for collection of tumor tissues for further studies.

\section{Tissue culture and cell line establishment}

Tumor tissue was minced (by crossed scalpels) in DMEM/
Ham's F12 cell culture media supplemented with 10\% FCS, $2 \mathrm{mM}$ L-glutamine and penicillin-streptomycin and passed through a cell strainer ( $100 \mu \mathrm{m}$; Becton-Dickinson-Falcon, Heidelberg, Germany) to obtain a single cell suspension. Cells were washed with PBS and seeded in 6-well plates coated with collagen. Outgrowing cells were detached with trypsin and transferred to T25 cell culture flasks. Cells passaged 2-3 times in this manner were transferred to T175 culture flasks and expanded for subsequent analyses. All cell culture plastics were from Greiner Bio One, Frickenhausen, Germany, and cell culture media and supplements were purchased from PAA, Cölbe, Germany.

\section{Phenotypic characterization (microphotography)}

Cells were cultured in T25 flasks to a confluence of $60-80 \%$ and photographed using the AxioVision 4.8.2 software (Carl Zeiss, Jena, Germany). Photographs were edited with Photoshop CS3 (Adobe, München, Germany).

\section{Growth kinetics}

Cells $\left(5 \times 10^{5}\right.$ cells $)$ were plated in $5 \mathrm{ml}$ media in quintuplicate T25 culture flasks per cell line and allowed to attach and grow for $48 \mathrm{~h}$. Cells were detached by trypsinization and the amount of vital cells was assessed by trypan blue staining using a Neubauer chamber. One flask was counted every $24 \mathrm{~h}$ for five consecutive days.

\section{Isolation of nucleic acids}

Genomic DNA (gDNA) from snap frozen tumor tissue and cell culture cell pellets $\left(3 \times 10^{6}\right.$ cells) was isolated using the Wizard Genomic DNA Purification Kit (Promega, Mannheim, Germany) according to the manufacturer's instructions. Total RNA from cell culture pellets $\left(3 \times 10^{6}\right.$ cells $)$ was isolated using the EURx Gene MATRIX Universal RNA Purification Kit (EURx, Gdansk, Poland) according to the manufacturer's instructions. Concentration of isolated nucleic acids was determined with the NanoDrop1000 (Thermo-Scientific, Wilmington, USA).

\section{cDNA synthesis}

$2 \mu \mathrm{g}$ total RNA was used for reverse transcription applying the High Capacity cDNA Reverse Transcription Kit according to the manufacturer's instructions (Applied Biosystems, Carlsbad, CA, USA).

\section{Molecular Characterization}

\section{MGMT promoter methylation}

For analyzing the MGMT promoter methylation, the MethyLight method was applied. Briefly, gDNA was subject to bisulfite conversion using the Epitect Bisulfite Kit (Qiagen, Hilden, Germany) according to the manufacturer's recommendations. A primer/probe combination specific for methylated MGMT promoter sequence was used, with the SensiFast Probe Kit (Bioline, Luckenwalde, Germany). CpGMethylase (SssI) (New England Biolabs, Frankfurt, Germany) treated DNA served as calibrator, since it is considered to be fully methylated. The collagenase gene 2A1 (COL2A1), was used as endogenous control. The percentage of methylated reference (PMR) value was calculated by dividing the MGMT/COL2A1 ratio of the sample by the MGMT/ COL2A1 ratio of the SssI-treated DNA, and multiplying by 100 . Samples with a PMR value $>4$ were considered as methylated [16]. All reactions were performed in triplicates. Used Primers are listed in Table 2 . 
Citation: Mullins CS, Schneider B, Lehmann A, Stockhammer F, Mann S, et al. (2014) A Comprehensive Approach to Patient-individual Glioblastoma Multiforme Model Establishment. J Cancer Sci Ther 6: 177-187. doi:10.4172/1948-5956.1000269

\begin{tabular}{|c|c|c|c|c|c|c|}
\hline Sample ID & Sex & Age & Diagnosis & Localization & Survival & Models \\
\hline HROG02 & M & 68 & GBM (IV) & $\mathrm{R}$; parietooccipital & $\dagger 7$ & C \\
\hline HROG03 & M & 50 & Anaplastic Oligodendroglioma (III) & $\mathrm{R}$; parietal & $? 9$ & \\
\hline HROG04 & $\mathrm{F}$ & 53 & Relapsed GBM (IV) & $\mathrm{R}$; frontal & $\dagger 13$ & C \\
\hline HROG05 & $\mathrm{F}$ & 60 & Relapsed GBM (IV) & L; temporal & † 3 & C, $X$ \\
\hline HROG06 & M & 53 & GBM (IV) & $\mathrm{L} ;$ frontal & $\dagger 8$ & C, $X$ \\
\hline HROG07 & M & 55 & Relapsed GBM (IV) & $\mathrm{R}$; temporoparietal & $\dagger 6$ & C \\
\hline HROG08 & M & 47 & Relapsed GBM (IV) & $\mathrm{R}$; frontal & $? 29$ & C \\
\hline HROG09 & M & 66 & Anaplastic Astrocytoma (II-III) & L; temporal & 33 & \\
\hline HROG10 & M & 74 & GBM (IV) & $\mathrm{R}$; temporal & $\dagger 7$ & C \\
\hline HROG11 & $\mathrm{F}$ & 54 & GBM (IV) & L; frontal & 30 & C \\
\hline HROG12 & M & 64 & GBM (IV) & $\mathrm{R}$; frontoparietal & $\dagger 5$ & $C, X$ \\
\hline HROG13 & $\mathrm{F}$ & 77 & GBM (IV) & L; temporal & $\dagger 8$ & C, $X^{*}$ \\
\hline HROG14 & $\mathrm{F}$ & 81 & Subependymoma (I) & IV. ventricle & † 3 & \\
\hline HROG15 & M & 56 & GBM (IV) & $\mathrm{R}$; parietal & 23 & C \\
\hline HROG16 & M & 53 & GBM (IV) & $\mathrm{R}$; parietal & $\dagger 26$ & \\
\hline HROG17 & M & 70 & Relapsed GBM (IV) & L; parietooccipital & $\dagger 3$ & C, $X$ \\
\hline HROG18 & M & 71 & Relapsed Oligoastrocytoma (II) & cerebrum & $? 7$ & \\
\hline HROG19 & M & 69 & GBM (IV) & L; temporoparietal & $\dagger 15$ & \\
\hline HROG20 & M & 34 & Diffuse Astrocytoma (II) & L; temporal & 24 & \\
\hline HROG21 & M & 44 & Secondary GBM (IV) & $\mathrm{R}$; parietal & 21 & C \\
\hline HROG22 & M & 66 & Relapsed GBM (IV) & L; temporal & $\dagger 4$ & \\
\hline HROG23 & $\mathrm{F}$ & 60 & Relapsed GBM (IV) & L; parietal & 20 & \\
\hline HROG24 & $\mathrm{F}$ & 73 & GBM (IV) & L; occipital & $\dagger 10$ & C \\
\hline HROG25 & $\mathrm{F}$ & 77 & Relapsed GBM (IV) & L; temporal & † 3 & \\
\hline HROG26 & M & 63 & Relapsed Astrocytoma (II) & $\mathrm{R}$; parietal & $\dagger 8$ & \\
\hline HROG27 & M & 76 & Meningioma (I) & cerebrum & 23 & \\
\hline HROG28 & $\mathrm{F}$ & 76 & Meningioma (I) & cerebrum & $? 4$ & \\
\hline HROG29 & M & 39 & Diffuse Oligoastrocytoma (II) & cerebrum & 19 & \\
\hline HROG30 & M & 67 & Meningioma (I) & frontal & $? 3$ & \\
\hline HROG31 & $\mathrm{F}$ & 59 & GBM (IV) & R; occipitotemporal & 21 & \\
\hline HROG32 & $\mathrm{F}$ & 76 & GBM (IV) & $\mathrm{R}$; temporal & 22 & \\
\hline HROG33 & $\mathrm{F}$ & 46 & GBM (IV) & L; occipitotemporal & $\dagger 13$ & $C, X$ \\
\hline HROG34 & $\mathrm{F}$ & 69 & GBM (IV) & L; frontal & $\dagger 5$ & \\
\hline HROG35 & M & 64 & Relapsed GBM (IV) & R; occipital & $\dagger 6$ & \\
\hline HROG36 & $\mathrm{F}$ & 80 & GBM (IV) & $\mathrm{R}$; parietal & $\dagger 5$ & C \\
\hline HROG37 & $\mathrm{F}$ & 20 & Pilocytic Astrocytoma (I) & L; occipital & $? 2$ & \\
\hline HROG38 & $\mathrm{F}$ & 49 & GBM (IV) & $\mathrm{R}$; parietooccipital & 19 & C \\
\hline HROG39 & $\mathrm{F}$ & 59 & Meningioma (I) & cerebrum & 18 & \\
\hline HROG41 & M & 71 & Secondary GBM (IV) & L; frontal & $\dagger 2$ & C \\
\hline HROG42 & $\mathrm{F}$ & 70 & GBM (IV) & L; frontal & 16 & \\
\hline HROG43 & M & 55 & Meningioma (I) & $\mathrm{L} ;$ frontal & $? 8$ & \\
\hline HROG44 & M & 69 & Meningioma (I) & L; frontal & ? 8 & \\
\hline HROG45 & M & 61 & relapsed Astrocytoma (II) & L; parietal & 13 & \\
\hline HROG46 & $\mathrm{F}$ & 69 & GBM (IV) & $\mathrm{R}$; parietotemporal & 15 & \\
\hline HROG47 & M & 59 & GBM (IV) & $\mathrm{R}$; temporal & $\dagger 16$ & \\
\hline HROG48 & M & 13 & Pilocytic Astrocytoma (I) & L; occipital & 13 & \\
\hline HROG49 & M & 45 & Relapsed secondary GBM (IV) & $\mathrm{R}$; parietooccipital & $? 6$ & \\
\hline HROG50 & $\mathrm{F}$ & 33 & Diffuse Oligoastrocytoma (II) & L; frontal & 14 & \\
\hline HROG52 & M & 47 & GBM (IV) & L; temporobasal & 13 & $\mathrm{X}$ \\
\hline HROG53 & $\mathrm{F}$ & 50 & Anaplastic Astrocytoma (III) & cerebrum & $? 4$ & \\
\hline HROG54 & M & 58 & GBM (IV) & $\mathrm{R}$; parietal & 8 & \\
\hline HROG55 & $\mathrm{F}$ & 74 & GBM (IV) & $\mathrm{R}$; parietal & $? 1$ & \\
\hline HROG56 & $\mathrm{F}$ & 76 & GBM (IV) & trigonum & $? 5$ & \\
\hline HORG57 & $\mathrm{F}$ & 60 & Relapsed GBM (IV) & $\mathrm{R}$; parietal & 8 & C \\
\hline HROG58 & $\mathrm{F}$ & 57 & GBM (IV) & $\mathrm{R}$; frontal & 7 & C \\
\hline HROG59 & M & 60 & Relapsed GBM (IV) & $\mathrm{R}$; temporal & $\dagger 8$ & $C, X$ \\
\hline HROG60 & M & 51 & Relapsed GBM (IV) & $\mathrm{R}$; temporal & $? 1$ & C \\
\hline HROG61 & $\mathrm{F}$ & 50 & diffuse Astrocytoma (II) & $\mathrm{L}$, frontal & 6 & C \\
\hline HROG62 & M & 71 & GBM (IV) & $\mathrm{R}$; temporoparietal & 4 & C \\
\hline HROG63 & M & 48 & Relapsed GBM (IV) & L; temporal & 3 & C \\
\hline HROG64 & $\mathrm{F}$ & 57 & GBM (IV) & R; temporal & 1 & \\
\hline
\end{tabular}

The table summarizes patient information on sex ( $\mathrm{F}=$ female; $\mathrm{M}=$ male), age at time point of resection in years, histological diagnosis including WHO grading in parentheses, tumor localization ( $\mathrm{L}=$ left hemisphere; $\mathrm{R}=$ right hemisphere) and survival ( $\dagger=$ patient died; bold=patients still alive on January $25^{\text {th }} 2013$; ?=no information available for $>6$ months) in months after resection. Successful cell line establishment is indicated by a $C$, cell lines characterized in the following are bold and establishment of xenografts by an $\mathrm{X}$. The $\mathrm{X}^{*}$ indicates that a xenograft could be established but was lost subsequently

Table 1: Patient and modeling data. 
Citation: Mullins CS, Schneider B, Lehmann A, Stockhammer F, Mann S, et al. (2014) A Comprehensive Approach to Patient-individual Glioblastoma Multiforme Model Establishment. J Cancer Sci Ther 6: 177-187. doi:10.4172/1948-5956.1000269

\section{Mutations (TP53, IDH 1 and 2, KRAS, BRAF, PTEN)}

Samples underwent analyses for the following loci: IDH 1 R132 (exon 4), IDH 2 R172 (exon 4), BRAF V600 (exon 15), KRAS G12, G13 (exon 2) and Q61 (exon 3), TP53 (exons 5 to 8) and full length PTEN (cDNA). The desired regions were amplified by PCR using specific primers (see Table 2). The PCR was performed using MyTaqHS polymerase (Bioline) according to the manufacturer's recommendations. The PCR reaction was controlled by agarose gel electrophoresis and $15 \mu \mathrm{l}$ of the products were purified using $3 \mathrm{U}$ of FAST AP Alkaline Phosphatase and 30U of Exonuclease I (Thermo Scientific, Schwerte, Germany) by incubation at $37^{\circ} \mathrm{C}$ for $15 \mathrm{~min}$ and subsequent heat inactivation at $85^{\circ} \mathrm{C}$ for $15 \mathrm{~min}$.

One microliter of the PCR product was used as template for Sanger sequencing using BigDye Terminator v1.1 Cycle Sequencing kit (Applied Biosystems, Darmstadt, Germany) and the primers used for PCR according to the manufacturer's protocol. The sequencing products were purified using the BigDyeXTerminator Purification kit (Applied Biosystems). The sequence was analyzed using the Applied Biosystems3500 genetic analyzer system and the SeqSape Software v2.7 (Applied Biosystems).

\section{EGFR amplification}

For determination of EGFR copy number, quantitative PCR was performed (primers see Table 2). 30 ng gDNA were used as template. The run was performed on a StepOneRealtime PCR system (Applied Biosystems) using Fast SYBR Green Mastermix (Applied Biosystems). Commercial normal human gDNA (Promega) was used as calibrator and the repetitive element LINE1 as endogenous control. The calculation of the EGFR copy number was performed using the $\Delta \Delta \mathrm{Ct}$ algorithm. All reactions were performed in triplicates.

\section{Chromosomal instability}

Chromosomal instability was assessed using the comparative genomic hybridization (CGH) based SNP Array 6.0 from Affymetrix (Cleveland, OH, USA) according to manufacturer's instructions.

\section{HLA typing}

A 2-digit resolution typing of the following HLA loci was performed: HLA-A, -B and -C and HLA-DR and-DQ.

\section{Flow cytometry}

Cells were harvested by incubation with trypsin; the enzymatic reaction was stopped by adding cell culture media. Cells were washed with PBS, counted and $5 \times 10^{5}$ cells were stained with $1 \mu \mathrm{g}$ of the respective antibody or isotype control (see Table 3 ) for staining cell surface molecules. Cells were washed with PBS and resuspended in a final volume of $200 \mu \mathrm{l}$ PBS. In case of unlabeled primary antibodies, excess antibody was washed out with PBS and respective secondary antibodies were added and final wash step was performed as above.

Similarly, $5 \times 10^{5}$ cells were fixed with $2 \%$ Formafix and then treated with buffer $\mathrm{P}$ for $10 \mathrm{~min}$ to permeabilize the cell membrane for an intra-cellular staining. Cells were incubated with the antibody and washed with buffer P. After a second 10 min incubation period the respective secondary antibody was added in buffer P. Cells were washed and resuspended in 2\% Formafix at a final volume of $200 \mu \mathrm{l}$.

For the staining method with unlabeled primary antibodies (see Table 3), cells handled the same way with no primary antibody served as negative controls. All incubations were performed on ice for $30 \mathrm{~min}$.

\section{Cytokine secretion (ELISA)}

Cells $\left(5 \times 10^{4}\right.$ cells) were plated in $5 \mathrm{ml}$ media per well in duplicates in 6-well culture plates and allowed to attach for $24 \mathrm{~h}$. The media were

\begin{tabular}{|c|c|c|}
\hline Target & $\begin{array}{l}\text { Primer sequence } \\
\text { forward }\end{array}$ & Reverse \\
\hline IDH 1 (Exon 4) & 5'-GCACGGTCTTCAGAGAAGCC-3' & 5'-CACATTATTGCCAACATGAC-3' \\
\hline IDH 2 (Exon 4) & 5'-GCCCACACATTTGCACTCTA-3' & 5'-CAGAGACAAGAGGATGGCTAGG-3' \\
\hline BRAF (Exon 15) & 5'-TCATAATGCTTGCTCTGATAGGA-3' & 5'-CTTTCTAGTAACTCAGCAGC-3' \\
\hline KRAS (Exon 2) & 5'-GTACTGGTGGAGTATTTGATAGTGTATTAA-3' & 5'-TCAAAGAATGGTCCTGCACC-3' \\
\hline KRAS (Exon 3) & 5'-CTTTGGAGCAGGAACAATGTCT-3' & 5'-TACACAAAGAAAGCCCTCCCC-3' \\
\hline TP53 (Exon 5) & 5'-GTTTCTTTGCTGCCGTCTTC-3' & 5'-GAGCAATCAGTGAGGAATCAGA-3' \\
\hline TP53 (Exon 6) & 5'AGAGACGACAGGGCTGGTT-3' & 5'-CAAATAAGCAGCAGGAGAAAGC-3' \\
\hline TP53 (Exon 7) & 5'AAAAAGGCCTCCССTGCT-3' & 5'-TGGAAGAAATCGGTAAGAGGTG-3' \\
\hline TP53 (Exon 8) & 5'-CAAGGGTGGTTGGGAGTAGA-3' & 5'-GAGGCAAGGAAAGGTGATAAAA-3' \\
\hline PTEN (segment 1) & 5'-TTCCATCCTGCAGAAGAAGC-3' & 5'-GCTGTGGTGGGTTATGGTCT-3' \\
\hline PTEN (segment 2) & 5'-ACCGCCAAATTTAATTGCAG-3' & 5'-CGCCACTGAACATTGGAATA-3' \\
\hline PTEN (segment 3) & 5'-GTGGCACTGTTGTTTCACAAG-3' & 5'-CTGCACGCTCTATACTGCAAA-3' \\
\hline PTEN (segment 4) & 5'ACCAGGACCAGAGGAAACCT-3' & 5'-AAGGTCCATTTTCAGTTTATTCAAG-3' \\
\hline EGFR & 5'-TCCCATGATGATCTGTCCCTCACA-3' & 5'-CAGGAAAATGCTGGCTGACCTAAG-3' \\
\hline LINE1 & 5'-TGCTTTGAATGCGTCCCAGAG-3' & 5'-AAAGCCGCTCAACTACATGG-3' \\
\hline MGMT methylation & 5'-GCGTTTCGACGTTCGTAGGT-3' & 5'-CACTCTTCCGAAAACGAAACG-3' \\
\hline Probe (MGMT) & \multicolumn{2}{|l|}{ 5'-6FAM-CGCAAACGATACGCACCGCGA-TMR-3' } \\
\hline MGMT expression & 5'-CCGAGGCTATCGAAGAGTTC-3' & 5'-TCCGAATTTCACAACCTTCA-3' \\
\hline COL2A1 & 5'-TCTAACAATTATAAACTCCAACCACCAA-3' & 5'-GGGAAGATGGGATAGAAGGGAATAT-3' \\
\hline Probe (COL2A1) & \multicolumn{2}{|c|}{ 5'-6FAM-CСТTCATTCTAACCCAATACCTATCCCACCTCTAAA-TMR-3' } \\
\hline PTEN expression & 5'ACCAGGACCAGAGGAAACCT-3' & 5'-CTGCACGCTCTATACTGCAAA-3' \\
\hline TBP & 5'-TCGGAGAGTTCTGGGATTGT-3' & 5'-CACGAAGTGCAATGGTCTTT-3' \\
\hline
\end{tabular}

The table lists all primers used in this study

Table 2: Primers 
replaced by fresh media or media not containing FCS (for TGF beta secretion). One $\mathrm{ml}$ samples of supernatant were collected on days 3 and 5 and stored at $-80^{\circ} \mathrm{C}$. For detection of cytokine production samples were unthawed on ice and $100 \mu \mathrm{l}$ supernatant was used for each ELISA assay. IL-6 (matched pair; Immunotools, Frisoythe, Germany), IL-8 (matched pair; Immunotools), TNF alpha (set pair; Immunotools), CEA (RayBio, Norcross, GA, USA) and TGF beta (Assaypro, St. Charles, MO, USA) ELISA assays were performed according to the manufacturer's instructions.

\section{Drug response}

Cells $\left(5 \times 10^{3}\right.$ cells) were plated in $150 \mu$ media per well in triplicate in 96-well flat bottom culture plates and allowed to attach for $24 \mathrm{~h}$. The following concentration ranges of drugs were tested (given are final concentrations in the experimental wells): (1) $500 \mu \mathrm{M}-32 \mathrm{nM} \mathrm{BCNU}$ (Bristol-Myers Squibb, New York, USA), (2) $500 \mu \mathrm{M}-32 \mathrm{nM}$ CCNU (Lomustine, Sigma-Aldrich, St. Louis, MO, USA), (3) $1 \mathrm{mM}-64 \mathrm{nM}$ Celecoxib (Molekula, München, Germany), (4) $30 \mu \mathrm{M}-30 \mathrm{nM}$ Cisplatin (Teva GmbH, Ulm, Germany), (5) $500 \mu \mathrm{M}-125$ nM Cytarabine (Cell Pharm GmbH, Bad Vilbel; Germany), (6) 1 mM-244 nM Irinotecan (Pfizer, Berlin, Germany), (7) $1 \mathrm{mM}-1 \mu \mathrm{M}$ Methotrexate (Teva GmbH), (8) $50 \mu \mathrm{M}-3.2 \mathrm{nM}$ Procarbazine (Natulan, Sigma-tau, Regensburg, Germany), (9) $30 \mu \mathrm{M}-30 \mathrm{nM}$ Rapamycin (Sirolimus, Pfizer), (10) 40 $\mu \mathrm{M}-10 \mathrm{nM}$ Thalidomide (Sigma-Aldrich), (11) $2 \mathrm{mM}-128 \mathrm{nM}$ TMZ (Sigma-Aldrich), (12) $5 \mu \mathrm{M}-320 \mathrm{pM}$ Topotecan (GlaxoSmithKline, Munich, Germany), (13) 244 nM-300 pM Vincristine (Hexal, Holzkirchen, Germany) and the therapeutic antibodies $2.5 \mathrm{mg} / \mathrm{ml}$ $39 \mathrm{ng} / \mathrm{ml}$ Bevacizumab (Avastin, Roche, Basel, Switzerland) and 20 $\mu \mathrm{g} / \mathrm{ml}-313 \mathrm{ng} / \mathrm{ml}$ Cetuximab (Erbitux, Bristol-Myers Squibb). Equal volumes DMSO (for cells treated with TMZ and BCNU) were added to cells serving as live control. Cells were incubated with the substances for $72 \mathrm{~h}$, and media were replaced together with substances in the same concentrations as before. After another $72 \mathrm{~h}$ incubation period cells serving as dead control were incubated with $70 \%$ ethanol for 30 min and viability was assessed by using the viability dye calcein AM (eBioscience, Frankfurt, Germany) in a final concentration of $0.7 \mu \mathrm{M}$ in fresh medium:PBS $(2: 1)$. Cells were incubated at $37^{\circ} \mathrm{C}$ in the dark for $20 \mathrm{~min}$, fluorescence intensity was assessed using the microplate reader Infinite M200 (Tecan, Mennedorf, Switzerland) with $485 \mathrm{~nm}$ excitation, $535 \mathrm{~nm}$ emission and a constant gain of 160 . Values were normalized ( $1=$ value live control; $0=$ value dead control).

\section{Statistics}

All statistics were performed with SigmaStat 3.5 (Systat Software $\mathrm{GmbH}$, Erkrath, Germany). $\mathrm{IC}_{50}$ values were calculated with Sigma Plot 10.0 (Systat Software GmbH).

\section{Results}

\section{Success rates}

We assessed attachment and outgrowth rates of 42 consecutive WHO grade IV GBM tumor samples in vitro and in vivo. Under standard in vitro conditions $37 / 42(88 \%)$ cells of the tumors attached; including 25/28 (89\%) newly diagnosed tumors and 12/14 (86\%) relapses. Establishment of outgrowing cell lines was successful in 25/42 cases $(60 \%)$, hereof $17 / 28$ (61\%) were derived from newly diagnosed tumors and 8/14 (57\%) from relapses. Twelve (8 newly diagnosed and 4 relapsed tumors) of the cell lines were very stable and rapidly dividing. These cell lines could be passaged over 40 times, which implies more than 50 cell divisions and thus exceeds the Hayflick limit (number of cell divisions a normal, healthy cell can undergo) and proves immortality [17]. Consequently, we consider them to be permanent cell lines (see Table 1).

Engraftment of patient tumor pieces into immunodeficient mice led to a tumor outgrowth in $8 / 36(22 \%)$ cases (see Table 1$)$. In seven of these (except HROG52), a patient derived cell line could be established in parallel. Of note, re-grafting of the obtained xenografts was always successful (data not shown).

\section{Morphology and growth kinetics}

The cell lines were micro-photographed to compare their morphology (Figure 1); all cell lines showed a fibroblast-like phenotype. Furthermore, doubling times of the cell lines were assessed and are presented in Figure 1. Doubling times ranged from $35 \mathrm{~h}$ for HROG36 to $89 \mathrm{~h}$ for HROG07. The average doubling time was $60 \mathrm{~h}$.

\section{Molecular data}

Molecular features of GBM such as the methylation status of the MGMT promoter, the amplification rate of EGFR, as well as mutation status of the genes IDH 1 and 2, TP53, KRAS, BRAF and PTEN were assessed in comparison to the original tumor material (Table 4). The methylation status of the MGMT promoter was consistent between original tumor and cell lines. Methylation of the promoter occurred in 11/42 tumors and was maintained in the cell lines HROG02, HROG05, HROG13, HROG15 and HROG17. This coincided with no or only marginal cDNA expression $(<0.001$; Table 4$)$. No methylation of the MGMT promoter was detectable in 27/42 tumors; for four samples the status could not be assessed; in two cases no snap frozen tumor tissue could be collected due to tumor size and in the two remaining cases no gDNA could be isolated due to a high degree of necrosis. The tumors HROG24 and HROG36 were scored unmethylated; however cDNA expression analyses revealed marginal expression of MGMT cDNA for both cell lines $(<0.001$; Table 4$)$. Further the cell lines HROG04, HROG06, HROG07, HROG10 and HROG38, which were also scored unmethylated, did express detectable levels of MGMT cDNA (Table 4).

All cell lines expressed detectable levels of PTEN cDNA; however, mutations in the gene were very frequently $(8 / 13 ; 62 \%)$ detected (HROG04, HROG05, HROG06, HROG15, HROG17, HROG24, HROG36 and HROG38). No mutations in PTEN were detected in cell lines HROG02, HROG07, HROG10, and HROG13.

A genomic amplification of the EGFR was present in 22/42 (52\%) tumors; 13 of these tumors had a high amplification $(>10 x)$. No amplification was detectable in 15/42 (36\%) tumors and five samples could not be analyzed. In one case no DNA could be isolated in the first place and in the four remaining cases only little DNA could be isolated and this was not sufficient to perform all molecular analyses. The amplification rate of the EGFR differed in eight (HROG02, HROG04, HROG05, HROG06, HROG07, HROG10, HROG17 and HROG24) out of the twelve cases when comparing the status of the original tumor to the one of the cell line (Table 4). Loss of the genomic EGFR amplification is a frequently described phenomenon in literature and explained by extra-chromosomal EGFR amplification (in form of mini-chromosomes) which is gradually lost in cell culture due to absence of selective pressure [18-20].

Of note, all mutations of the original tumors were maintained in the cell lines except those affecting IDH 1. HROG02, HROG06, HROG15 
Citation: Mullins CS, Schneider B, Lehmann A, Stockhammer F, Mann S, et al. (2014) A Comprehensive Approach to Patient-individual Glioblastoma Multiforme Model Establishment. J Cancer Sci Ther 6: 177-187. doi:10.4172/1948-5956.1000269

\begin{tabular}{|c|c|c|c|c|}
\hline Species & Target & Clone & Label & Manufacturer \\
\hline Mouse & CD15 & MEM-158 & PE & Immunotools (Friesoythe, Germany) \\
\hline Mouse & CD24 & SN3 & $\mathrm{PE}$ & Immunotools \\
\hline Mouse & CD34 & $-581-$ & PE & Immunotools \\
\hline Mouse & CD44 & MEM-85 & APC & Immunotools \\
\hline Mouse & CD90 & AS02 & FITC & Dianova (Hamburg, Germany) \\
\hline Mouse & CD133 & AC133 & PE & Miltenyi (BergischGladbach, Germany) \\
\hline Mouse & GFAP & GA5 & FITC & eBioscience (Frankfurt, Germany) \\
\hline Mouse & Nestin & $10 \mathrm{C} 2$ & FITC & eBioscience \\
\hline Mouse & S-100 & B32.1 & None & Abcam (Cambridge, United Kingdom) \\
\hline Mouse & Vimentin & V9 & None & Abcam \\
\hline Goat & Mouse & polyclonal & $\mathrm{PE}$ & DakoCytomation (Hamburg, Germany) \\
\hline
\end{tabular}

The table lists all antibodies used in this study for flow cytometry

Table 3: Antibodies.

\begin{tabular}{|c|c|c|c|c|c|c|c|}
\hline Sample ID & & $\begin{array}{l}\text { MGMT } \\
\text { promoter status }\end{array}$ & cDNA expression & PTEN & EGFR [ $x$ fold] & Mutations & $\begin{array}{l}\text { Molecular } \\
\text { sub-classification }\end{array}$ \\
\hline HROG02 & $\begin{array}{l}\text { tumor } \\
\text { cell line }\end{array}$ & M & $<0.001$ & 3.68 & $\begin{array}{l}3 \\
1\end{array}$ & TP53 R248Q & $\begin{array}{l}\text { Proneural } \\
\text { TP53 mut; 4q12 (PDGFRA) amplified }\end{array}$ \\
\hline HROG04 & $\begin{array}{l}\text { tumor } \\
\text { cell line }\end{array}$ & $U$ & 1.02 & 12.73 & $\begin{array}{l}36 \\
1\end{array}$ & PTEN W274L & $\begin{array}{l}\text { Classical } \\
\text { EGFR amplified; 9p21.3 (CDKN2A) deleted }\end{array}$ \\
\hline HROG05 & $\begin{array}{l}\text { tumor } \\
\text { cell line }\end{array}$ & M & $<0.001$ & 1.01 & $\begin{array}{l}82 \\
1\end{array}$ & $\begin{array}{l}\text { KRAS G12D } \\
\text { PTEN P169S/del 212-229 }\end{array}$ & $\begin{array}{l}\text { Mesenchymal* } \\
\text { PTEN mutated }\end{array}$ \\
\hline HROG06 & $\begin{array}{l}\text { tumor } \\
\text { cell line }\end{array}$ & $U$ & 0.07 & 2.31 & $\begin{array}{l}82 \\
1\end{array}$ & $\begin{array}{l}\text { TP53 R273H/R306* } \\
\text { PTEN (+1 at } 126)\end{array}$ & $\begin{array}{l}\text { Proneural } \\
\text { TP53 mutated; 4q12 (PDGFRA) amplified }\end{array}$ \\
\hline HROG07 & $\begin{array}{l}\text { tumor } \\
\text { cell line }\end{array}$ & $U$ & 0.34 & 14.92 & $\begin{array}{l}12 \\
1\end{array}$ & wt & $\begin{array}{l}\text { Classical } \\
\text { EGFR amplified; 9p21.3 (CDKN2A) deleted }\end{array}$ \\
\hline HROG10 & $\begin{array}{l}\text { tumor } \\
\text { cell line }\end{array}$ & $U$ & 0.27 & 3.73 & $\begin{array}{l}2 \\
1\end{array}$ & wt & $\begin{array}{l}\text { Proneural } \\
\text { 4q12 (PDGFRA) amplified }\end{array}$ \\
\hline HROG13 & $\begin{array}{l}\text { tumor } \\
\text { cell line }\end{array}$ & M & $<0.001$ & 2.88 & $\begin{array}{l}1 \\
1\end{array}$ & wt & $\begin{array}{l}\text { Classical } \\
\text { chr.7 amplified; chr.10 lost; 9p21.3 (CDKN2A) } \\
\text { deleted }\end{array}$ \\
\hline HROG15 & cell line & M & $<0.001$ & 3.70 & 1 & $\begin{array}{l}\text { TP53 R273H } \\
\text { PTEN S170N }\end{array}$ & $\begin{array}{l}\text { Mesenchymal } \\
\text { PTEN mutated; } 17 q 11.2(\mathrm{NF}) \text { deleted }\end{array}$ \\
\hline HROG17 & $\begin{array}{l}\text { tumor } \\
\text { cell line }\end{array}$ & M & $<0.001$ & 0.55 & $\begin{array}{l}4 \\
1\end{array}$ & PTEN R130* & $\begin{array}{l}\text { Mesenchymal* } \\
\text { PTEN mutated }\end{array}$ \\
\hline HROG24 & $\begin{array}{l}\text { tumor } \\
\text { cell line }\end{array}$ & $U$ & $<0.001$ & 2.21 & $\begin{array}{l}43 \\
1\end{array}$ & $\begin{array}{l}\text { TP53 R273C } \\
\text { MGMT CN=1 } \\
\text { PTEN exon } 3 \text { del/spliced }\end{array}$ & $\begin{array}{l}\text { Proneural } \\
\text { TP53 mutated; 4q12 (PDFRA) amplified }\end{array}$ \\
\hline HROG36 & $\begin{array}{l}\text { tumor } \\
\text { cell line }\end{array}$ & $U$ & $<0.001$ & 3.72 & $\begin{array}{l}1 \\
1\end{array}$ & $\begin{array}{l}\text { MGMT CN=0 } \\
\text { PTEN I5S }\end{array}$ & $\begin{array}{l}\text { Mesenchymal* } \\
\text { PTEN mutated }\end{array}$ \\
\hline HROG38 & $\begin{array}{l}\text { tumor } \\
\text { cell line }\end{array}$ & U & 0.23 & 0.02 & $\begin{array}{l}1 \\
1\end{array}$ & PTEN I224M/R234W & $\begin{array}{l}\text { Mesenchymal* } \\
\text { PTEN mutated }\end{array}$ \\
\hline
\end{tabular}

This table summarizes molecular characteristics of tumors in comparison to the corresponding cell line. The moleclular data was then used for sub-typing according to Verhaak et al. [7]. Listed are the methylation status of the MGMT promoter (M=methylated; $U$ =unmethylated), the relative cDNA expression of the MGMT gene compared to the housekeeping gene TBP, the relative cDNA expression of the PTEN gene compared to the housekeeping gene TBP, the genomic amplification rate of the EGFR compared to the normal diploid status $(1=2 n)$ and detected mutations of the genes TP53, PTEN, IDH 1 and 2 , KRAS and BRAF (wt=wild type, if no mutations were detected; mutations are indicated by the position with the wt amino acid in front and the amino acid resulting from the mutation behind or * in case of a stop codon; $\mathrm{CN}=\mathrm{copy}$ number 1 , when one copy of the gene was lost and 0 if both copies of the gene were lost; del=deletion of amino acids; spliced=alternatively spliced; $+1=$ insertion of a base leading to a frame shift)

Table 4: Molecular characteristics.

and HROG24 show a mutation in the TP53 gene; HROG05 has a mutation in the KRAS gene. One mutation of BRAF was detected in the tumor HROG23 (no successful culture, data not shown). Mutations in the gene IDH 1 were present in tumors HROG21 (still in culture but very slowly growing) and HROG41; the mutation however was not maintained in the cell line HROG41 (data not shown). The MGMT gene was completely deleted in HROG36 and only one allele was left in HROG24.

No mutations in the analyzed genes were detected in tumors and cell lines HROG07, HROG10 andHROG13.

\section{CGH array}

A variety of chromosomal abnormalities are described for GBM (see above). For a detailed analysis addressing this issue in the GBM cell line collection (except for HROG38), a genomic analysis with very high resolution taking advantage of the SNP Array 6.0 from Affymetrix was performed. All except one cell line (HROG07) showed almost complete loss of at least one copy of chromosome 10. Chromosome 13q was deleted in 4/11 (HROG02, HROG05, HROG24 and HROG36). The most frequent amplification was for chromosome 7; in 8/11 cases an amplification was present (HROG04, HROG05, HROG06, HROG13, 
Citation: Mullins CS, Schneider B, Lehmann A, Stockhammer F, Mann S, et al. (2014) A Comprehensive Approach to Patient-individual Glioblastoma Multiforme Model Establishment. J Cancer Sci Ther 6: 177-187. doi:10.4172/1948-5956.1000269

HROG15, HROG17, HROG24 and HROG36). The long arm of chromosome 9 (9q) was amplified in cell lines HROG02, HROG04, HROG05, HROG07, HROG17 and HROG36. Merely cell line HROG13 had a deletion at $1 \mathrm{p}$ and HROG36 at 19q; no co-deletions of the loci were detected (for a detailed view sees supplementary Figure 1).

\section{Molecular sub-typing}

According to the molecular data and pieces of information obtained by the $\mathrm{CGH}$ arrays, an attempt at sub-classifying the cell lines into the proneural, neural, mesenchymal and classical GBM types was undertaken (see Table 4). All but four cell lines could easily be assigned to one specific sub-type. The cell lines HROG05, HROG17, HROG36 and HROG38 could not be categorized definitely. Despite the fact that HROG05, HROG17 and HROG36 lacked the loss of 17q11.2 and for HROG38 no CGH data was available, they were assigned into the mesenchymal sub-type; basing on the fact that all four cell lines had mutated PTEN genes and since the mesenchymal sub-type is the most common one described for GBM cell lines [7].

All in all, 5/12 (42\%) cell lines were categorized as/assigned to the mesenchymal sub-type, $4 / 12(33 \%)$ were categorized as proneural and $3 / 12(25 \%)$ as classical sub-type. None of the cell lines was classified as neuronal sub-type, which mainly is due to the lack of robust markers here for [7].

\section{Neuronal and cell surface marker expression}

The expression of neuronal markers such as GFAP, nestin, vimentin and S-100 as well as GBM (associated) cell surface and Brain Tumor Stem Cell (BTSC) markers was analyzed by flow cytometry (see Figure 2). In all cell lines general expression of neuronal markers was detectable (Figure 2A). A high level of general GBM (associated) markers was detectable. The degree of expressed BTSC markers varied from cell line to cell line, but a small positive population was always present (Figure 2B).

\section{Cytokine secretion}

The level of secreted cytokines with immunosuppressive and/ or tumor relevant functions was assessed. All but one (HROG38) GBM cell line secreted high levels of IL-8. High secretion of IL-6 was detectable in 6/12 (50\%) cell lines: HROG06, HROG10, HROG15, HROG17, HROG24 and HROG36. Little IL-6 was present in the
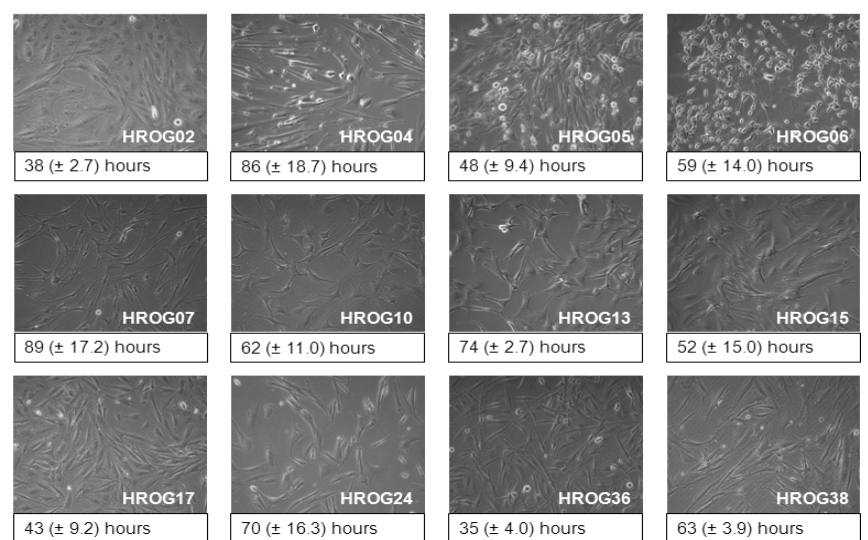

Figure 1: Cell line morphology and doubling times. Depicted in this figure are micro-photographed pictures (100x enlarged) and doubling times in hours $( \pm$ standard deviation) of the cell lines.
A

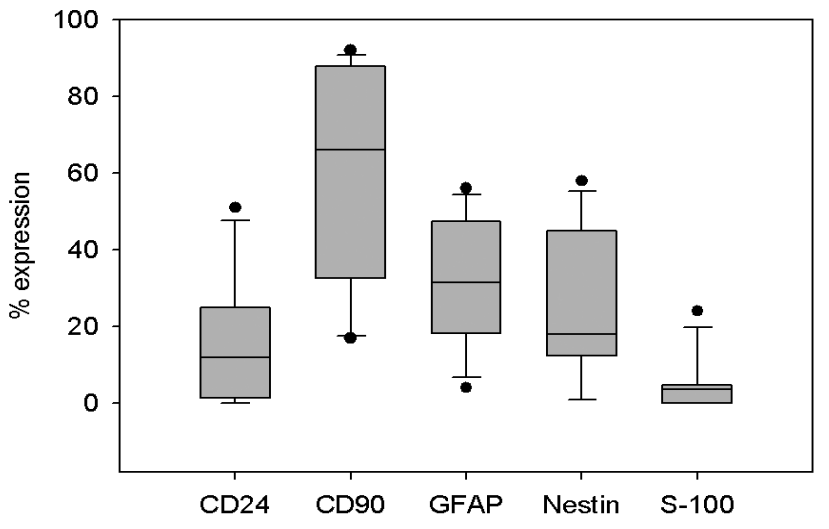

B

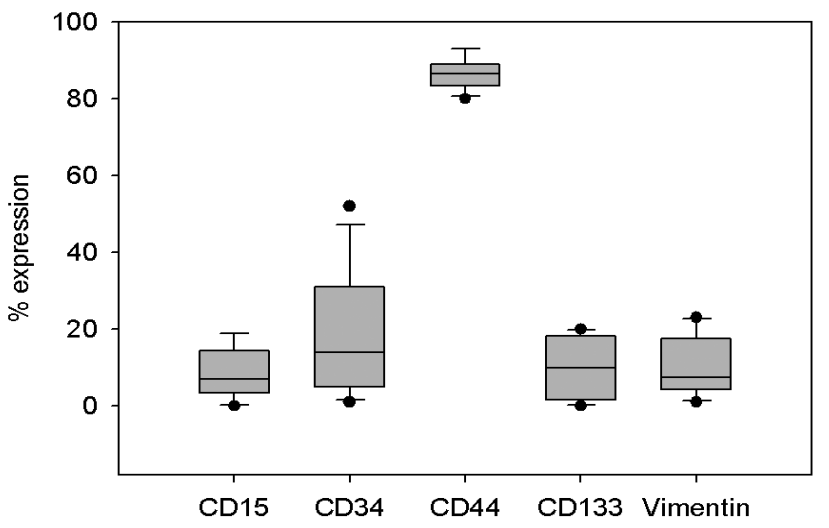

Figure 2: Expression of neuronal and BTSC markers. The percentage of cells expressing (A) cell surface GBM markers (CD24 and CD90) as well as intracellular expression of neuronal proteins (GFAP, Nestin and S-100) as well as (B) BTSC markers (CD15, CD34, CD44, CD133 and Vimentin) are depicted in the boxplot graphic. The grey box represents middle $50 \%$ of values; the line in the box is the median expression; whiskers indicate the range of the data set; outliers are plotted as dots. Data are derived from three independent analyses.

supernatant of HROG05; and cell lines HROG02, HROG04, HROG07, HROG13 and HROG38 secreted no IL-6. Merely, the cell line HROG04 secreted some TGF beta (see Table 5). None of the cell lines secreted CEA or TNF alpha (data not shown).

\section{HLA typing and tumor (associated) antigens}

For future development of immunotherapeutic strategies a twodigits encompassing HLA typing was performed on the cell lines (see Table 6). The analyses revealed that $10 / 12(83 \%)$ cell lines were HLA-A2 positive.

The cell lines were further analyzed for the expression of tumor associated antigens (TAA) such as CEA, IL-13 receptor alpha (IL13Ra), TGF beta and HIP-1; all in the discussion as being relevant in GBM tumors [21-25].

Rather high levels of CEA were detectable in all cell lines. In contrast, the degree of GBM TAA varied less from cell line to cell line; generally only few cells stained positive for GBM TAA, yet a small positive population was always present (Figure 3). 
Citation: Mullins CS, Schneider B, Lehmann A, Stockhammer F, Mann S, et al. (2014) A Comprehensive Approach to Patient-individual Glioblastoma Multiforme Model Establishment. J Cancer Sci Ther 6: 177-187. doi:10.4172/1948-5956.1000269

\begin{tabular}{|c|c|c|c|}
\hline Sample ID & IL-6 $[\mathbf{p g} / \mathbf{m l}]$ & $\mathbf{I L - 8}[\mathbf{p g} / \mathbf{m l}]$ & TGF- $\boldsymbol{\beta}[\mathbf{p g} / \mathbf{m l}]$ \\
\hline HROG02 & 0.0 & $482.0 / 483.0$ & 0.0 \\
\hline HROG04 & 0.0 & $240.0 / 316.0$ & $131.0 / 70.0$ \\
\hline HROG05 & $0.0 / 13.3$ & $498.0 / 477.0$ & 0.0 \\
\hline HROG06 & $197.5 / 204.4$ & $213.0 / 264.0$ & 0.0 \\
\hline HROG07 & 0.0 & $347.0 / 281.0$ & 0.0 \\
\hline HROG10 & $794.6 / 0.0$ & $544.0 / 304.0$ & 0.0 \\
\hline HROG13 & 0.0 & $559.0 / 394.0$ & 0.0 \\
\hline HROG15 & $612.8 / 625.5$ & $514.0 / 495.0$ & 0.0 \\
\hline HROG17 & $658.8 / 656.0$ & $519.0 / 520.0$ & 0.0 \\
\hline HROG24 & $413.6 / 493.3$ & $395.0 / 418.0$ & 0.0 \\
\hline HROG36 & $478.8 / 708.0$ & $502.0 / 526.0$ & 0.0 \\
\hline HROG38 & 0.0 & $0.0 / 11.0$ & 0.0 \\
\hline
\end{tabular}

The amount of cytokines secreted after 72 hours (value before the slash) and 120 hours (value after the slash) of cell culture are listed

Table 5: Cytokine secretion.

\begin{tabular}{|c|c|c|c|c|c|c|c|c|c|c|}
\hline \multirow{3}{*}{$\begin{array}{l}\text { Sample ID } \\
\text { HROG02 } \\
\end{array}$} & \multicolumn{6}{|c|}{ HLA class I } & \multicolumn{4}{|c|}{ HLA class II } \\
\hline & \multicolumn{2}{|c|}{ A } & \multicolumn{2}{|c|}{ B } & \multicolumn{2}{|c|}{ C } & \multicolumn{2}{|c|}{ DRB1 } & \multicolumn{2}{|c|}{ DQB1 } \\
\hline & ${ }^{*} 01$ & ${ }^{*} 02$ & *08 & *13 & ${ }^{*} 06$ & ${ }^{*} 07$ & ${ }^{*} 03$ & ${ }^{*} 07$ & ${ }^{*} 02$ & - \\
\hline HROG04 & ${ }^{*} 01$ & ${ }^{*} 02$ & *08 & ${ }^{*} 51$ & ${ }^{*} 07$ & *15 & ${ }^{*} 03$ & *11 & *02 & ${ }^{*} 03$ \\
\hline HROG05 & ${ }^{*} 02$ & - & ${ }^{*} 07$ & ${ }^{*} 40$ & ${ }^{*} 03$ & ${ }^{*} 07$ & *12 & *13 & ${ }^{*} 03$ & ${ }^{*} 06$ \\
\hline HROG06 & ${ }^{*} 01$ & ${ }^{*} 03$ & ${ }^{*} 08$ & *35 & ${ }^{*} 04$ & ${ }^{*} 07$ & ${ }^{*} 01$ & *13 & *05 & ${ }^{*} 06$ \\
\hline HROG07 & ${ }^{*} 02$ & ${ }^{*} 26$ & *15 & ${ }^{*} 27$ & ${ }^{*} 03$ & ${ }^{*} 07$ & ${ }^{*} 08$ & *15 & *06 & - \\
\hline HROG10 & ${ }^{*} 02$ & *23 & *15 & *44 & ${ }^{*} 01$ & ${ }^{*} 04$ & ${ }^{*} 07$ & ${ }^{*} 09$ & *02 & ${ }^{*} 03$ \\
\hline HROG13 & ${ }^{*} 02$ & - & *15 & ${ }^{*} 44$ & *03 & ${ }^{*} 05$ & ${ }^{*} 03$ & ${ }^{*} 06$ & *04 & *13 \\
\hline HROG15 & ${ }^{*} 02$ & ${ }^{*} 03$ & *15 & *35 & ${ }^{*} 03$ & ${ }^{*} 04$ & ${ }^{*} 03$ & *13 & ${ }^{*} 02$ & ${ }^{*} 06$ \\
\hline HROG17 & *11 & *66 & *14 & $* 40$ & ${ }^{*} 01$ & ${ }^{*} 08$ & ${ }^{*} 01$ & *12 & *03 & *05 \\
\hline HROG24 & *02 & - & *40 & *44 & *02 & ${ }^{*} 05$ & ${ }^{*} 07$ & *13 & ${ }^{*} 02$ & *06 \\
\hline HROG36 & ${ }^{*} 02$ & ${ }^{*} 25$ & $* 40$ & *55 & ${ }^{*} 03$ & - & ${ }^{*} 04$ & *14 & ${ }^{*} 03$ & ${ }^{*} 05$ \\
\hline HROG38 & ${ }^{*} 02$ & *11 & *13 & *51 & ${ }^{*} 03$ & ${ }^{*} 06$ & ${ }^{*} 04$ & ${ }^{*} 09$ & ${ }^{*} 03$ & - \\
\hline
\end{tabular}

The results of a 2 digits encompassing HLA typing for the loci HLA-A, $-B$ and $-C$ as wells as HLA-DR and DQ are listed. Information on both alleles is provided; in case of homozygosity the "second" allele is marked by -

Table 6: HLA typing.

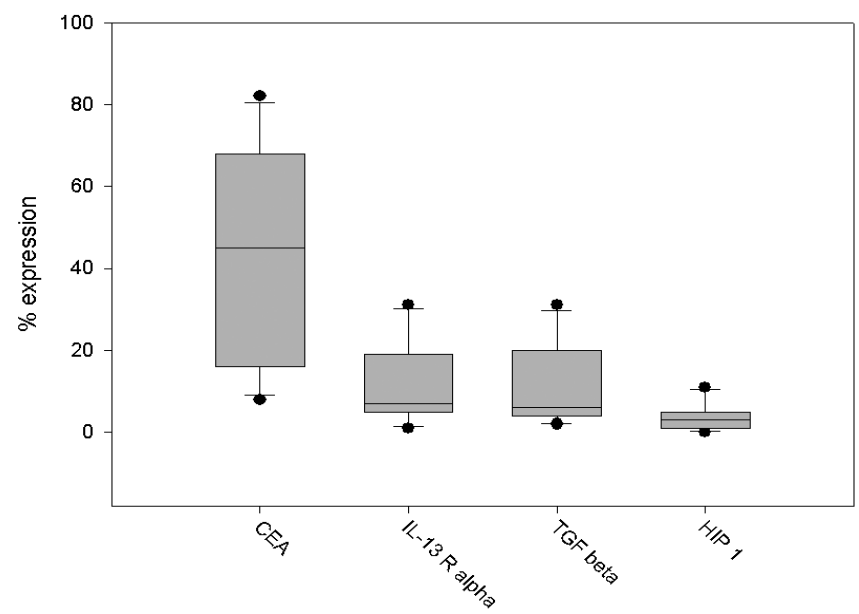

Figure 3: Expression of TAA. The percentage of cells expressing general and GBM specific TAA as CEA, IL-13Ra, TGF- $\beta$ and HIP1 is depicted in the boxplot graphic. The grey box represents middle $50 \%$ of values; the line in the box is the median expression; whiskers indicate the range of the data set; outliers are plotted as dots.

\section{Drug response}

Finally, response of the GBM cell lines to increasing doses of therapeutic agents was assessed ( $\mathrm{IC}_{50}$ values; Table 7 ). Sensitivity to an agent varied between cell lines and sensitivity of a cell line to various agents differed as well. For CCNU, Cisplatin, Cytarabine and Topotecan a correlation with the methylation status of the MGMT promoter or with cDNA expression levels were found. In vitro sensitivity was significantly higher in hypermethylated (cDNA expression $<0.001$ ) cell lines; with $\mathrm{p}=0.033$ for CCNU, $\mathrm{p}=0.002$ for Cisplatin, $\mathrm{p}=0.016$ for Cytarabine and $\mathrm{p}=0.024$ for Topotecan. In the case of the remaining alkylating substances BCNU, Procarbazine and TMZ, however, no correlation of sensitivity towards the agents and the

\begin{tabular}{|c|c|c|c|c|c|c|c|c|c|c|}
\hline$\frac{\frac{0}{0}}{\frac{0}{0}}$ & $\begin{array}{l}\sum_{3} \\
\sum \\
\text { Z } \\
0\end{array}$ & $\begin{array}{l}\frac{\sum}{3} \\
\vdots \\
\vdots \\
0\end{array}$ & 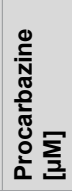 & 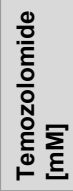 & $\begin{array}{l}\sum \\
\sum \\
\frac{\sum}{3} \\
\frac{\pi}{0} \\
\frac{0}{0} \\
\frac{0}{0}\end{array}$ & 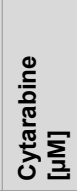 & 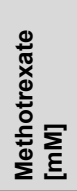 & 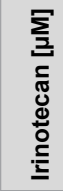 & 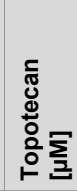 & 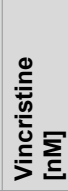 \\
\hline HROG02 & 68.0 & 20.0 & 20.0 & 2.0 & 1.0 & 1.0 & $>1.0$ & 0.07 & 0.02 & 2.0 \\
\hline HROG04 & 209.0 & 241.0 & 33.3 & 3.5 & $>30$ & $>500$ & $>1.0$ & 2.0 & 3.0 & 4.0 \\
\hline HROG05 & 110.0 & 137.0 & 35.7 & 1.2 & 4.0 & 0.5 & $>1.0$ & 0.6 & 0.02 & 0.3 \\
\hline HROG06 & 111.8 & 98.3 & 37.2 & 0.5 & 10.0 & 500 & $>1.0$ & 0.07 & 0.1 & 18.0 \\
\hline HROG07 & 279.0 & 359.0 & 38.7 & 2.0 & $>30$ & $>500$ & $>1.0$ & 28.0 & 1.5 & 244 \\
\hline HROG10 & 158.0 & 101.0 & 25.0 & 1.5 & 16.3 & $>500$ & $>1.0$ & 65.5 & 1.2 & 244 \\
\hline HROG13 & 312.0 & 198.0 & 34.4 & 2.0 & 12.0 & $>500$ & $>1.0$ & 58.8 & 1.2 & 200 \\
\hline HROG15 & 52.0 & 101.0 & 35.7 & 0.8 & 7.0 & 3.7 & $>1.0$ & 0.07 & 0.02 & 3.6 \\
\hline HROG17 & 21.3 & 61.0 & 3.8 & 0.05 & 3.2 & 0.1 & $>1.0$ & 0.07 & 0.01 & 1.4 \\
\hline HROG24 & 28.3 & 21.8 & 30.1 & 0.2 & 1.3 & 3.8 & $>1.0$ & 0.03 & 0.02 & 9.0 \\
\hline HROG36 & 46.0 & 27.5 & 31.6 & 1.2 & 3.2 & 0.5 & $>1.0$ & 0.1 & 0.01 & 1.8 \\
\hline HROG38 & 136.6 & 237.4 & 32.6 & 1.0 & 17.0 & 32.0 & $>1.0$ & 0.8 & 1.0 & 1.8 \\
\hline
\end{tabular}

Calculated IC $\mathrm{I}_{50}$ values (from three independent assessments in triplicates) for 144 hour incubation periods with the therapeutic agents are provided for all cell lines

Table 7a: Drug sensitivity for conventional chemotherapeutics (IC ${ }_{50}$ values).

\begin{tabular}{|c|c|c|c|c|c|}
\hline $\begin{array}{l}\frac{0}{\frac{0}{0}} \\
\frac{0}{\overline{0}} \\
\text { ஸे }\end{array}$ & 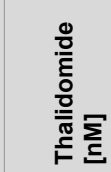 & 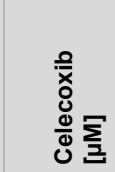 & 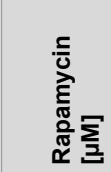 & 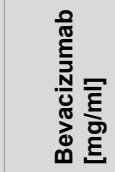 & 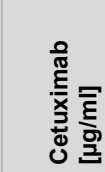 \\
\hline HROG02 & $>40$ & 68 & 1.0 & $>2.5$ & $>20$ \\
\hline HROG04 & $>40$ & 48 & 1.0 & $>2.5$ & $>20$ \\
\hline HROG05 & 40 & 51 & 1.5 & $>2.5$ & $>20$ \\
\hline HROG06 & $>40$ & 126 & 3.0 & $>2.5$ & $>20$ \\
\hline HROG07 & $>40$ & 171 & 6.0 & $>2.5$ & $>20$ \\
\hline HROG10 & $>40$ & 74 & 6.0 & $>2.5$ & $>20$ \\
\hline HROG13 & $>40$ & 60 & 2.7 & $>2.5$ & $>20$ \\
\hline HROG15 & $>40$ & 67 & 3.0 & $>2.5$ & $>20$ \\
\hline HROG17 & 0.62 & 58 & 0.4 & $>2.5$ & $>20$ \\
\hline HROG24 & $>40$ & 68 & 0.9 & $>2.5$ & $>20$ \\
\hline HROG36 & 10.0 & 60 & 2.4 & $>2.5$ & $>20$ \\
\hline HROG38 & $>40$ & 68 & 31.0 & $>2.5$ & $>20$ \\
\hline
\end{tabular}

Calculated $I C_{50}$ values (after three independent assessments in triplicates) for 144 hour incubation with the therapeutic agents are provided for all cell lines

Table $7 \mathrm{~b}$ : Drug sensitivity for novel and targeted therapeutics $\left(\mathrm{IC}_{50}\right.$ values). 
methylation status of the MGMT promoter were observed. A general strong in vitro response to Vincristine was detected, yet the greatest variance between the different cell lines was observed for this substance ( $\mathrm{IC}_{50}$ values ranged from $0.3 \mathrm{nM}$ to $244 \mathrm{nM}$ ). In the five most sensitive to Irinotecan (HROG02, HROG06, HROG15, HROG17, HROG24), all four cell lines with mutated TP53 (HROG02, HROG06, HROG15 and HROG24) were found. In terms of serum level achievable amounts, Methotrexate had no influence on cell viability in vitro. None of the three cell lines most sensitive to Thalidomide had detectable MGMT cDNA expression (>0.001), the cell lines HROG05 and HROG17 were methylated and in HROG36 the MGMT gene was completely deleted. The ranges of the $\mathrm{IC}_{50}$ values for Celecoxib was rather narrow (48-171 $\mu \mathrm{M})$

\section{Discussion}

In the present study we aimed at generating a collection of GBM models reflecting the clinical appearance of GBM cases. Prime focus was characterizing the GBM models in detail for subsequent translational approaches such as response prediction and therapy development.

Final establishment of permanent growing cell lines was more successful than in vivo engraftment; contrary to success rates for colorectal carcinomas in our group [26] but very much in line with data from the literature [27].

The HROG cell line establishment rates are for the most part superior to what is described in literature with success rates ranging from $3 \%$ for pediatric brain tumors [28] over $10 \%$ [29] to $21 \%$ [30] for adult GBM tumors. However, most authors do not comment on any statistics at all. The most stably outgrowing and subsequently characterized twelve cell lines of our collection included eight newly diagnosed and four relapsed tumors, meaning successful establishment of an immortal and stably growing cell line in $29 \%$ of cases for both newly diagnosed and relapsed tumors. There are another 13 cultures also stably outgrowing but not yet fully characterized mainly due to very high doubling times ( $>100$ hours). When possible, characterization(s) are continuously ongoing (e.g. HROG33, HROG41, HROG59 and HROG63).

On the pro side of in vitro models are the fast and easily feasible method and high success rates [27] thus cell cultures provide a good model for a first drug screen on response and resistance development. Subsequent testing and verification may then more selectively be performed using in vivo model(s) - preferably established in parallel to the cell lines.

One major drawback of tumor models in general is a trend towards genetic drift (in comparison to the original tumor material) [31]. Therefore, the GBM models generated in this work were compared to the primary GBM tumor tissue presented to the pathologist for routine diagnosis. High preservation of the primary GBM tumor's molecular features was achieved in the models. The only exceptions observed concerned the mutation status of the IDH 1 gene, which is not maintained in the in vivo models, and the genomic amplification of the EGFR which is lost during standard in vitro culturing processes. Both phenomena are well described in literature [18-20].

The extensive molecular pathological analyses are not only required for detailed diagnosis but also have clinical relevance. In breast carcinoma patients the HER2/neu receptor is relevant for therapy with the monoclonal antibody Trastuzumab; only patients with an amplification of the HER2/neu receptor profit of this therapy
[32]. For GBM patients not responding to the first line therapy (radio-chemotherapy with TMZ) a variety of alternatives including targeted therapeutics are available. Patients with amplification of EGFR may receive monoclonal antibodies directed against this receptor. However, effectiveness of these antibodies seems to be restricted to the expression of the wild type form of the receptor [33]. Bevacizumab is an antibody directed against the growth factor VEGF and thus could inhibit tumor vascularization and (neo-) angiogenesis [34].

Many recent studies, i.e. clinical testing of targeted therapeutics, have not led to the expected results but rather fell short of the high expectations [35]. This is to a big part attributable to the very heterogeneous nature of GBM tumors [35] and thus comes as no big surprise. Apparently, if the great heterogeneity is not adequately considered when recruiting for clinical studies, possible beneficial effects for individual GBM sub-types may be undetected. In line with this argumentation is the initiative to sub-classify GBM tumors into the categories proneural, neural, mesenchymal and classical by designating specific molecular characteristics to these sub-groups [7]. The gene signature described by Duarte and coworkers [13] might have strong implications both for better prediction models for survival and improved understanding of the underlying subtype-specific molecular mechanisms for GBM tumor progression and treatment response.

A key feature of cancer development is the progressive accumulation of genomic alterations resulting in the loss of tumor suppressor functions, the activation of oncogenes and the generation of fusion genes with oncogenic potential [36]. Such complex structural and numerical alterations in the genome leading to changes in the DNA copy number are characteristic also of GBM tumors [37].

Beside defining and uncovering tumor initiating, propagating and metastasizing processes, and identifying new (molecular) target structures, high throughput screening of drugs is one main field of tumor model usage; especially cell lines for the latter. Cell cultures are broadly used since cell lines are easy to handle, and manageable in high quantities; they represent a relatively low-cost approach and are ethically preferable to methods utilizing experimental animals [38]. Thus they have somewhat become the pharmaceutical industries favorite "pet". However, one big obstacle remains. Cell lines established in the 1970s and 1980s, when there was a big hype for GBM cell lines [27] have been passaged very frequently and mostly even uncounted times and certainly have "acquired" culturing artifacts. Many changes over long term in vitro culturing are well described. Extensive in vitro passaging may lead to a hypermethylated phenotype. In this respect, Danam and colleagues demonstrated that with increasing cell culture passage, methylation progressively increased and revealed a concomitant trend to a completely MGMT-silenced phenotype [39]. Acquisition of "new" mutations and chromosomal aberrations are further described for highly passaged cell lines [27]. These (very) long term cultures have little in common with the original situation in the patients and thus only have limited model capability and drug testing potential.

The gold standard chemotherapeutic agent for GBM tumors is since 2005 TMZ [40,41]. All novel therapeutics must measure up to it and prove significant benefit for GBM patients or lower toxicity towards normal tissue, i.e. have fewer side effects. We assessed responsiveness of the patient-derived low passage GBM cell line collection towards a broad range of chemotherapeutics. The sensitivity to CCNU, Cisplatin, Cytarabine and Topotecan correlated with the methylation status of the MGMT promoter or MGMT cDNA expression and was significantly 
higher in hypermethylated cell lines. No correlation of the methylation status of the MGMT promoter could be detected for the agents BCNU, TMZ and Procarbazine. This is somewhat in contrast to the positive correlation described for methylated MGMT promoter and response to alkylating agents [3]. However, the presence of MGMT cDNA tended to correlate with a better response in methylated cell lines. This emphasizes the value of these patient-derived low passage cell lines since detailed characterization revealed for example a deletion of the entire MGMT sequence in HROG36 which was scored unmethylated but did not even harbor the sequence. The same holds true for HROG24 with only one copy of the MGMT gene. Methylation scoring for such cases may have to be reconsidered. Responses to Irinotecan and Topotecan tended to be strongest for cell lines with mutated TP53. This finding goes well with the fact that GBM cells treated with the DNA topoisomerase inhibitor SN-38 only underwent cell cycle arrest and even re-proliferated after withdrawal of the inhibitor in a wild type TP53 setting, whereas in cells with mutations in the tumor suppressor, treatment caused apoptosis [42]. Thalidomide, initially applied as a sedative, has proven anti-cancer efficacy [43,44]. Three cell lines: HROG05, HROG17 and HROG36 were highly responsive to the agent. Currently Lenalidomide (derived from Thalidomide; CC-5013) is under clinical investigation for treatment of advanced cancers and GBM in particular (NCT00165447, NCT00036894, NCT00671801 and NCT01183663).

The cancer stem cell hypothesis was initiated in the 1990s by Dick and colleagues [45]. Their report on Leukemia initiating cells became the paradigm for later studies proposing cancer stem cells to be at the top of a hierarchical pyramid [46]. A number of strategies has been developed and tested to treat GBM tumors by specifically targeting brain tumor stem cells; e.g. by miRNA [47], CD133 specific antibodies [48] or by vaccination with brain tumor stem cell loaded dendritic cells [49].

In summary, our novel patient-derived (ultra-) low passage cell lines and matched xenografts represent model systems with ideal features for response and resistance prediction, and, since they are molecularly and clinically well characterized, will be essential tools for the next steps towards truly individualized therapy.

\section{Acknowledgements}

This work was supported by the "Wilhelm Vaillant Stiftung", a funding program of the university medicine Rostock (FORUN) and a graduate scholarship of the state Mecklenburg-Vorpommern to CSM. The authors want to thank Dr. Dirk Koczan for performing the SNP6.0 analyses. The authors declare that no conflicts of interest exist.

\section{References}

1. Preusser M, de Ribaupierre S, Wöhrer A, Erridge SC, Hegi M, et al. (2011) Current concepts and management of glioblastoma. Ann Neurol 70: 9-21.

2. Henriksson R, Asklund T, Poulsen HS (2011) Impact of therapy on quality of life, neurocognitive function and their correlates in glioblastoma multiforme: a review. J Neurooncol 104: 639-646.

3. Hegi ME, Diserens AC, Gorlia T, Hamou MF, de Tribolet N, et al. (2005) MGMT gene silencing and benefit from temozolomide in glioblastoma. $\mathrm{N}$ Engl $\mathrm{J}$ Med 352: $997-1003$

4. Alves TR, Lima FR, Kahn SA, Lobo D, Dubois LG, et al. (2011) Glioblastoma cells: a heterogeneous and fatal tumor interacting with the parenchyma. Life Sci 89: 532-539.

5. Louis DN, Ohgaki H, Wiestler OD, Cavenee WK, Burger PC, et al. (2007) The 2007 WHO classification of tumours of the central nervous system. Acta Neuropathol 114: 97-109.

6. Ohgaki H, Kleihues $P$ (2013) The definition of primary and secondary glioblastoma. Clin Cancer Res 19: 764-772.
7. Verhaak RG, Hoadley KA, Purdom E, Wang V, Qi Y, et al. (2010) Integrated genomic analysis identifies clinically relevant subtypes of glioblastoma characterized by abnormalities in PDGFRA, IDH1, EGFR, and NF1. Cancer Cell 17: 98-110.

8. Masui K, Cloughesy TF, Mischel PS (2012) Review: molecular pathology in adult high-grade gliomas: from molecular diagnostics to target therapies. Neuropathol Appl Neurobiol 38: 271-291.

9. Bleeker FE, Molenaar RJ, Leenstra S (2012) Recent advances in the molecular understanding of glioblastoma. J Neurooncol 108: 11-27.

10. Nagane M, Lin H, Cavenee WK, Huang HJ (2001) Aberrant receptor signaling in human malignant gliomas: mechanisms and therapeutic implications. Cancer Lett 162: S17-17S21.

11. Hatanpaa KJ, Burma S, Zhao D, Habib AA (2010) Epidermal growth factor receptor in glioma: signal transduction, neuropathology, imaging, and radioresistance. Neoplasia 12: 675-684.

12. Hill C, Hunter SB, Brat DJ (2003) Genetic markers in glioblastoma: prognostic significance and future therapeutic implications. Adv Anat Pathol 10: 212-217.

13. Duarte CW, Willey CD, Zhi D, Cui X, Harris JJ, et al. (2012) Expression signature of IFN/STAT1 signaling genes predicts poor survival outcome in glioblastoma multiforme in a subtype-specific manner. PLoS One 7: e29653.

14. Voskoglou-Nomikos T, Pater JL, Seymour L (2003) Clinical predictive value of the in vitro cell line, human xenograft, and mouse allograft preclinical cancer models. Clin Cancer Res 9: 4227-4239.

15. Fiebig HH, Maier A, Burger AM (2004) Clonogenic assay with established human tumour xenografts: correlation of in vitro to in vivo activity as a basis for anticancer drug discovery. Eur J Cancer 40: 802-820.

16. Ogino S, Brahmandam M, Kawasaki T, Kirkner GJ, Loda M, et al. (2006) Epigenetic profiling of synchronous colorectal neoplasias by quantitative DNA methylation analysis. Mod Pathol 19: 1083-1090.

17. Hayflick $L$ (1980) Recent advances in the cell biology of aging. Mech Ageing Dev 14: 59-79.

18. Bigner SH, Humphrey PA, Wong AJ, Vogelstein B, Mark J, et al. (1990) Characterization of the epidermal growth factor receptor in human glioma cell lines and xenografts. Cancer Res 50: 8017-8022.

19. Pandita A, Aldape KD, Zadeh G, Guha A, James CD (2004) Contrasting in vivo and in vitro fates of glioblastoma cell subpopulations with amplified EGFR. Genes Chromosomes Cancer 39: 29-36.

20. Witusik-Perkowska M, Rieske $P$, HuÅ,as-Bigoszewska K, Zakrzewska $M$, Stawski R, et al. (2011) Glioblastoma-derived spheroid cultures as an experimental model for analysis of EGFR anomalies. J Neurooncol 102: 395407.

21. Bradley SV, Holland EC, Liu GY, Thomas D, Hyun TS, et al. (2007) Huntingtin interacting protein 1 is a novel brain tumor marker that associates with epidermal growth factor receptor. Cancer Res 67: 3609-3615.

22. Debinski W, Gibo DM, Slagle B, Powers SK, Gillespie GY (1999) Receptor for interleukin 13 is abundantly and specifically over-expressed in patients with glioblastoma multiforme. Int J Oncol 15: 481-486.

23. Debinski W, Slagle B, Gibo DM, Powers SK, Gillespie GY (2000) Expression of a restrictive receptor for interleukin 13 is associated with glial transformation. $J$ Neurooncol 48: 103-111.

24. d'Aquino S, La Torre F, Tomasello R, Palmara D, Giacobello T, et al. (1985) [Immunohistochemical study on the presence of CEA in primary brain tumors. Preliminary note]. Minerva Med 76: 1587-1591.

25. Joseph JV, Balasubramaniyan V, Walenkamp A, Kruyt FA (2013) TGF- $\beta$ as a therapeutic target in high grade gliomas - promises and challenges. Biochem Pharmacol 85: 478-485.

26. Linnebacher M, Maletzki C, Ostwald C, Klier U, Krohn M, et al. (2010) Cryopreservation of human colorectal carcinomas prior to xenografting. BMC Cancer 10: 362

27. Huszthy PC, Daphu I, Niclou SP, Stieber D, Nigro JM, et al. (2012) In vivo models of primary brain tumors: pitfalls and perspectives. Neuro Oncol 14: 979993.

28. Xu J, Erdreich-Epstein A, Gonzalez-Gomez I, Melendez EY, Smbatyan G, et al (2012) Novel cell lines established from pediatric brain tumors. J Neurooncol 107: 269-280. 
Citation: Mullins CS, Schneider B, Lehmann A, Stockhammer F, Mann S, et al. (2014) A Comprehensive Approach to Patient-individual Glioblastoma Multiforme Model Establishment. J Cancer Sci Ther 6: 177-187. doi:10.4172/1948-5956.1000269

29. Maunoury R (1977) Establishment and characterization of 5 human cell lines derived from a series of 50 primary intracranial tumors. Acta Neuropathol 39: 33-41.

30. Stockhausen MT, Broholm H, Villingshøj M, Kirchhoff M, Gerdes T, et al. (2011) Maintenance of EGFR and EGFRvIll expressions in an in vivo and in vitro model of human glioblastoma multiforme. Exp Cell Res 317: 1513-1526.

31. Capes-Davis A, Reid YA, Kline MC, Storts DR, Strauss E, et al. (2013) Match criteria for human cell line authentication: where do we draw the line? Int J Cancer 132: 2510-2519.

32. Montserrat M, Leveque D, Barthelemy P, Bergerat JP (2012) Duration of adjuvant trastuzumab treatment in routine practice. Anticancer Res 32: 45854588.

33. Gajadhar AS, Bogdanovic E, Muñoz DM, Guha A (2012) In situ analysis of mutant EGFRs prevalent in glioblastoma multiforme reveals aberrant dimerization, activation, and differential response to anti-EGFR targeted therapy. Mol Cancer Res 10: 428-440.

34. LaViolette PS, Cohen AD, Prah MA, Rand SD, Connelly J, et al. (2013) Vascular change measured with independent component analysis of dynamic susceptibility contrast MRI predicts bevacizumab response in high-grade glioma. Neuro Oncol 15: 442-450.

35. Wang Y, Jiang T (2013) Understanding high grade glioma: molecular mechanism, therapy and comprehensive management. Cancer Lett 331: 139146

36. Forment JV, Kaidi A, Jackson SP (2012) Chromothripsis and cancer: causes and consequences of chromosome shattering. Nat Rev Cancer 12: 663-670.

37. Ruano Y, Mollejo M, Camacho FI, Rodríguez de Lope A, Fiaño C, et al. (2008) Identification of survival-related genes of the phosphatidylinositol 3'-kinase signaling pathway in glioblastoma multiforme. Cancer 112: 1575-1584

38. Matarese G, La Cava A, Horvath TL (2012) In vivo veritas, in vitro artificia Trends Mol Med 18: 439-442.

39. Danam RP, Howell SR, Remack JS, Brent TP (2001) Heterogeneous methylation of the $\mathrm{O}(6)$-methylguanine-DNA methyltransferase promoter in immortalized IMR90 cell lines. Int J Oncol 18: 1187-1193.

40. Piaskowski S, Bienkowski M, Stoczynska-Fidelus E, Stawski R, Sieruta M et al. (2011) Glioma cells showing IDH1 mutation cannot be propagated in standard cell culture conditions. Br J Cancer 104: 968-970.

41. Stupp R, Mason WP, van den Bent MJ, Weller M, Fisher B, et al. (2005) Radiotherapy plus concomitant and adjuvant temozolomide for glioblastoma. N Engl J Med 352: 987-996.

42. Wang Y, Zhu S, Cloughesy TF, Liau LM, Mischel PS (2004) p53 disruption profoundly alters the response of human glioblastoma cells to DNA topoisomerase I inhibition. Oncogene 23: 1283-1290.

43. Kumar S, Witzig TE, Rajkumar SV (2002) Thalidomide as an anti-cancer agent J Cell Mol Med 6: 160-174.

44. Thomas DA, Kantarjian HM (2000) Current role of thalidomide in cancer treatment. Curr Opin Oncol 12: 564-573.

45. Lapidot T, Sirard C, Vormoor J, Murdoch B, Hoang T, et al. (1994) A cell initiating human acute myeloid leukaemia after transplantation into SCID mice. Nature 367: 645-648.

46. Rosen JM, Jordan CT (2009) The increasing complexity of the cancer stem cell paradigm. Science 324: 1670-1673.

47. Yang YP, Chien Y, Chiou GY, Cherng JY, Wang ML, et al. (2012) Inhibition of cancer stem cell-like properties and reduced chemoradioresistance of glioblastoma using microRNA145 with cationic polyurethane-short branch PEI. Biomaterials 33: 1462-1476.

48. Wang CH, Chiou SH, Chou CP, Chen YC, Huang YJ, et al. (2011) Photothermolysis of glioblastoma stem-like cells targeted by carbon nanotubes conjugated with CD133 monoclonal antibody. Nanomedicine 7: 69-79.

49. Xu Q, Liu G, Yuan X, Xu M, Wang H, et al. (2009) Antigen-specific T-cell response from dendritic cell vaccination using cancer stem-like cell-associated antigens. Stem Cells 27: 1734-1740.
Citation: Mullins CS, Schneider B, Lehmann A, Stockhammer F, Mann S, et al. (2014) A Comprehensive Approach to Patient-individual Glioblastoma Multiforme Model Establishment. J Cancer Sci Ther 6: 177-187. doi:10.4172/1948-5956.1000269 